\title{
Chemical composition of corn silage produced by scientific studies in Brazil - A meta-analysis
}

\section{Composição bromatológica de silagens de milho produzidas em condições experimentais no Brasil - Metanálise}

\author{
Pagiel Bernardi Zardin ${ }^{1}$; João Pedro Velho ${ }^{2 *}$; Clóves Cabreira Jobim³ \\ Dileta Regina Moro Alessio ${ }^{4}$; Ione Maria Pereira Haygert-Velho²; \\ Gabriel Menegazzi da Conceição ${ }^{1}$; Paulo Sérgio Gois Almeida ${ }^{2}$
}

\begin{abstract}
The objective of the present study was to perform a meta-analysis that compared the chemical composition of corn silage produced for different experimental purposes, i.e., by research groups that studied corn silage (SCS) or by research groups that only used corn silage (UCS) as a form of roughage. We analyzed 203 papers that were published between January 1994 and December 2014 and contained a total of 647 treatments and the analysis of 1701 silos. We found a significant difference $(\mathrm{P}<0.0001)$ in the dry matter (DM) content of SCS silage (33.00\%) and that of UCS silage (30.64\%). The DM contents of neutral detergent fiber for the SCS and UCS silage were high (54.72 and 55.14\% DM, respectively) but were not significantly different from one another $(\mathrm{P}=0.5936)$, and the acid detergent fiber content of the UCS silage (31.04\% DM) was higher than that of the SCS silage $(29.65 \%, \mathrm{P}=0.0214)$, which indicated that the UCS silage was less digestible than the SCS silage. This was also corroborated ( $\mathrm{P}=$ $0.0064)$ by the mean content of total digestible nutrients $(64.18 \% \mathrm{DM})$ in the UCS silage, which likely results from the lower level of care taken when using standard silage production methods, compared to that taken by SCS researchers. Therefore, we concluded that the corn silage produced by research groups in Brazil are not analyzed in full and that, as a result, there is a paucity of important information, such as the content of organic acids. In addition, we also found that corn silage produced in Brazil contains a high level of neutral detergent fiber.
\end{abstract}

Key words: Starch. Carbohydrate. Fiber. Ruminant. Conserved roughage. Zea mays.

\section{Resumo}

Objetivou-se analisar metanaliticamente a composição bromatológica de silagens de milho, estudadas ou utilizadas em dietas para ruminantes, em condições experimentais brasileiras. Foram utilizados artigos publicados entre janeiro de 1994 e dezembro de 2014, totalizando 203 artigos científicos com 647 tratamentos, envolvendo a análise de 1.701 silos. Observou-se diferença $(\mathrm{P}<0,0001)$ no teor de matéria seca (MS) encontrado nas silagens entre pesquisas que estudam especificamente silagem de milho (ESM, de 33,00\% de MS), para as que utilizam silagem de milho como suporte em outras avaliações

\footnotetext{
${ }^{1}$ Discentes, Curso de Graduação em Zootecnia, Universidade Federal de Santa Maria, UFSM, Campus de Palmeira das Missões, Palmeira das Missões, RS, Brasil. E-mail: pagiel_zardin@hotmail.com; gabriel_menegazzi_conceicao@hotmail.com

2 Profs. Adjuntos, Departamento de Zootecnia e Ciências Biológicas, UFSM, Campus de Palmeira das Missões, Palmeira das Missões, RS, Brasil. E-mail: velhojp@ufsm.br; ione.h.velho@ufsm.br; pauloalmeida@smail.ufsm.br

${ }^{3}$ Prof. Associado, Departamento de Zootecnia, Universidade Estadual de Maringá, UEM, Maringá, PR, Brasil. E-mail: ccjobim@ uem.br

${ }^{4}$ Discente, Curso de Doutorado do Programa de Pós-Graduação em Ciência Animal, Universidade do Estado de Santa Catarina, UDESC, Lages, SC, Brasil. E-mail: alessiodrm@gmail.com

* Author for correspondence
} 
científicas USM, 30,64\% de MS). Os teores de fibra em detergente neutro são elevados para ESM $(54,72 \%$ da MS) e para USM $(55,14 \%$ da MS), não havendo diferença $(\mathrm{P}=0,5936)$. As USM apresentam valores maiores $(\mathrm{P}=0,0214)$ de fibra em detergente ácido (FDA) $(31,04 \%$ da MS), ou seja, fornecem volumoso de menor digestibilidade que as ESM. Este fato é também corroborado $(\mathrm{P}=0,0064)$ pelo nível médio de nutrientes digestíveis totais (NDT) (64,18\% da MS) nos estudos USM, pois geralmente não há o mesmo cuidado com as premissas básicas de produção de silagem, comparado com o grupo ESM cujas silagens apresentaram em média $29,65 \%$ de FDA e $66,79 \%$ de NDT. As silagens de milho de planta inteira produzidas em condições experimentais no Brasil não são analisadas por completo, faltam informações imprescindíveis como o teor de ácidos orgânicos. Além disso, apresentam alto teor de fibra em detergente neutro.

Palavras-chave: Amido. Carboidrato. Fibra. Ruminante. Volumoso conservado. Zea mays.

\section{Introduction}

Corn silage is one of the main forages fed to dairy cows and finishing feedlot cattle in Brazil, as well as in many other countries around the globe. Some of the main reasons that corn silage is used include its high capacity for dry matter production, easy harvesting, suitability for silo fermentation, digestible neutral detergent fiber content, and high concentration of net energy. These characteristics allow producers to reduce the use of feed concentrates, without impairing the physiology and performance of the animals (SILVA et al., 2015). In addition, the characteristics of corn, coupled with the meteorological, extension and territorial soil conditions of Brazil, have also spurred several research groups to investigate means for improving corn cultivation, as well as for improving the production and use of silage. However, research groups with other interests and goals often only use silage as roughage in feeds.

The fermentation, management, and use of corn silage takes at least 180 days, from the choice of cultivation area and treatment with limestone and fertilizer to its voluntary intake by animals in the production system. However, the time required to complete the process varies, since it depends on several factors, including the initial fertility of the soil, weather conditions, cycle of the hybrid (days), fermentation time, and time needed to open the silo and use the silage. Therefore, it is imperative that the quality of the silage is sufficient to enhance the performance and productivity of the animals, in order to profit production companies, and it is essential to conduct quality control, since the cost of cultivating corn is greater than that of other silage crops grown in Brazil (e.g., sorghum, pearl millet, grasses). One indicator to assess quality control throughout the silage production process is through its complete chemical composition, but it is not always achieved. Therefore, parameters, such as dry matter, mineral matter, $\mathrm{pH}$, neutral detergent fiber, and starch, should be evaluated in both ensilage and silage to assess the initial quality of forage and also the process of ensiling and to ensure that the fermentation is necessary to determine organic acids.

Considering published studies that have investigated or used corn silage, systematic studies can be developed. According to Luiz (2002), a meta-analysis aims to extract additional information from existing data, by combining the data of several studies and applying one or more statistical techniques. Meta-analysis has been reported as a useful statistical method for objectively evaluating research data (SAUVANT et al., 2008; MARÍN et al., 2015), and the strategy also has the potential to facilitate discoveries based on published literature, since it can provide greater statistical power than individual studies, owing to the substantial increase in sample size (RABIEE et al., 2012).

Accordingly, the objective of the present study was to perform a meta-analysis of corn silage produced by research groups in Brazil, in order to compare the chemical composition of silage from 
studies that focused on improving the production, management, and use of silage and that of silage from studies that only used silage as roughage.

\section{Material and Methods}

We constructed a database of publicly available scientific papers by searching the Scientific Electronic Library Online (SciELO), CAPES Periodic Portal, and Google Scholar, using "corn silage" as a keyword, and we categorized the articles into those that specifically studied corn silage (SCS) and those that only used corn silage (UCS). Subsequently, each of the articles was read for later tabulation of data in Excel, following the basic premises indicated by Lovatto et al. (2007), where each articles can only be deleted at the time of statistical analysis, and only those articles that reported the complete or partial chemical composition of corn silage that was produced for scientific studies in Brazil were included in the database.

The tabulated data were from experiments published between January 1994 and December 2014, which included 203 experiments with 647 treatments and involved the analysis of 1701 silos (Annex 1). For each of the articles, we extracted the chemical composition data, including values reported for dry matter (DM), organic matter, total carbohydrates, non-fibrous carbohydrates (NFC), starch, neutral detergent fiber (NDF), NDF corrected for ash and protein (NDFap), acid detergent fiber, cellulose, hemicelluloses, lignin detergent acid, crude protein, ammoniacal nitrogen $\left(\mathrm{N}-\mathrm{NH}_{3} /\right.$ Total $\left.\mathrm{N}\right)$, lactic acid, $\mathrm{pH}$, ether extract, in vitro digestibility of DM, total digestible nutrients, net energy, calcium, and phosphorus.

The data were analyzed statistically using the Means and Univariate procedures and analysis of variance, using the Mixed procedure of the SAS statistical software (SAS INSTITUTE, 2002), by the method of restricted maximum likelihood (REML). The REML method is highly recommended for analyzing unbalanced data, which is typical of meta-analysis data, since the same variables are not usually reported by each study (HENDERSON, 1975; SAS INSTITUTE, 2002). In the REML method, each observation is divided into two independent parts, related to fixed and random effects, which eliminates the bias that results from the loss of degrees of freedom when fixed effects are estimated, and, therefore, provides unbiased estimators for unbalanced data, as well as minimum variance values for balanced data. For the analysis of variance, we used the purpose of silage production (i.e., SCS and UCS) as the fixed effect and the number of silos per treatment as the random effect; and we compared mean values using the Tukey-Kramer test, with a probability level of 5\%.

\section{Results and Discussion}

Even in published scientific studies, we found that the chemical composition of corn silage was not fully analyzed (Table 1). Some variables were intensely evaluated, such as crude protein content $(\mathrm{N}=563)$. However, crude protein content has little effect on the quality of silage because it only represents a mean of $7.56 \%$ of the total silage constituents, and when silage processing is conducted according to basic established procedures, the crude protein content does not significantly affect the quality of silage. This variable was most likely evaluated by studies because it is the most popular nutrient in rural enterprises and the results also among researchers.

Determining DM content is the starting point of any chemical composition analysis. Therefore, it was the most commonly reported variable. Since mineral matter can be measured simultaneously, when measuring DM content using the method of Weende, we expected that mineral matter would be frequently reported, as well. However, we found that the variable was only analyzed in $44.27 \%$ of the studies, according to the frequency of the reported organic matter content. The amplitude of DM content (Table 1) indicated that the minimum value (19.2\%) 
could affect the fermentation process, owing to high water activity $\left(\mathrm{a}_{\mathrm{w}}\right)$, whereas the maximum value $(50.5 \%)$ could hamper the compaction of the silage. The DM content has a direct effect on the compression of silage, which influences its porosity and deterioration during storage and use (JOBIM et al., 2007).

Table 1 Descriptive statistics of corn silage produced by scientific studies in Brazil.

\begin{tabular}{|c|c|c|c|c|c|}
\hline \multirow{2}{*}{ Variables } & \multicolumn{5}{|c|}{ Descriptive statistics } \\
\hline & $\mathrm{N}^{*}$ & Minimum & Mean & Maximum & $\mathrm{SE}$ \\
\hline Dry matter 1 & 585 & 19.20 & 32.52 & 50.50 & 0.24 \\
\hline Organic matter ${ }^{2}$ & 259 & 84.82 & 94.98 & 99.07 & 0.13 \\
\hline Total carbohydrates ${ }^{2}$ & 212 & 78.62 & 84.99 & 90.50 & 0.14 \\
\hline Non fibrous carbohydrates ${ }^{2}$ & 185 & 7.53 & 29.18 & 54.28 & 0.67 \\
\hline $\mathrm{Starch}^{2}$ & 59 & 2.34 & 20.15 & 38.60 & 0.99 \\
\hline Neutral detergent fiber ${ }^{2}$ & 543 & 36.20 & 54.82 & 77.53 & 0.32 \\
\hline NDFap $^{2}$ & 46 & 35.65 & 52.46 & 71.02 & 1.23 \\
\hline Acid detergent fiber ${ }^{2}$ & 422 & 16.23 & 29.93 & 50.52 & 0.24 \\
\hline Cellulose $^{2}$ & 44 & 15.40 & 24.28 & 36.30 & 0.57 \\
\hline Hemicellulose $^{2}$ & 414 & 8.93 & 24.57 & 41.16 & 0.24 \\
\hline Lignin $^{2}$ & 155 & 2.53 & 5.41 & 13.11 & 0.17 \\
\hline Crude protein ${ }^{2}$ & 563 & 3.90 & 7.56 & 12.60 & 0.05 \\
\hline Ammoniacal nitrogen ${ }^{3}$ & 147 & 1.46 & 4.95 & 14.22 & 0.19 \\
\hline Lactic acid ${ }^{2}$ & 43 & 1.00 & 5.38 & 14.80 & 0.52 \\
\hline $\mathrm{pH}$ & 216 & 3.20 & 3.76 & 5.10 & 0.02 \\
\hline Ether extract ${ }^{2}$ & 234 & 0.43 & 2.84 & 6.65 & 0.06 \\
\hline IVDMD $^{2}$ & 103 & 46.14 & 65.09 & 76.26 & 0.79 \\
\hline Total digestible nutrients ${ }^{2}$ & 132 & 47.70 & 66.30 & 75.48 & 0.38 \\
\hline Net energy ${ }^{4}$ & 60 & 1.20 & 1.53 & 1.74 & 0.02 \\
\hline Calcium $^{2}$ & 95 & 0.03 & 0.17 & 0.47 & 0.01 \\
\hline Phosphorus $^{2}$ & 90 & 0.04 & 0.19 & 0.53 & 0.01 \\
\hline
\end{tabular}

*Number of observations; 1 = percentage of natural matter; 2 = Percentage of dry matter; 3 = Percentage of total nitrogen; $4=$ Megacalorie per kilogram of dry matter; NDFap = neutral detergent fiber content corrected for ash and protein content; IVDMD = in vitro dry matter digestibility.

The nutrient contents of livestock feed are based on DM content. A significant difference was observed between the DM content of the SCS (33.00\% of natural matter and UCS $30.64 \%$ of natural matter) silage ( $\mathrm{P}<0.0001$; Table 2$)$, which confirmed our expectation that SCS research groups better monitor the moment of harvest corn plants. The optimum stage for harvesting corn plants for silage production is when the digestible DM ha- ${ }^{-1}$ reaches its maximum, which is when the NDF content is diluted by the increasing starch content from grain filling (NUSSIO et al., 2001). This stage occurs when the grains develop a hard chalky consistency (R5) and the DM content ranges from $30 \%$ to $35 \%$ of natural matter (RESENDE et al.,
2005). At this stage, good conditions of fermentation and preservation of silage are found, corresponding to high voluntary intake by cattle, which results in higher animal performance.

Carbohydrates make up the major components of ruminant diets. Therefore, the total carbohydrate content is very important for meeting the energy requirements for livestock maintenance and production, as well as for fulfilling its role in microbial protein synthesis. Our analysis revealed that total carbohydrates account for an average of $85.37 \%$ of the DM content of silage $(\mathrm{N}=212$; Table 2 ); however, there was no difference in the total carbohydrate content of SCS and UCS silage. 
Table 2. Chemical composition of corn silage in Brazilian experiments produced with different purposes.

\begin{tabular}{|c|c|c|c|c|c|c|}
\hline \multirow{2}{*}{ Variables } & \multicolumn{4}{|c|}{ Purpose of corn silage } & \multirow{2}{*}{ SE } & \multirow{2}{*}{$P$} \\
\hline & $\mathrm{N}^{*}$ & SCS & $\mathrm{N}$ & UCS & & \\
\hline Dry matter $^{1}$ & 466 & 33.00 & 119 & 30.64 & 0.57 & $<0.0001$ \\
\hline Organic matter ${ }^{2}$ & 168 & 95.01 & 91 & 94.91 & 0.27 & 0.7121 \\
\hline Total carbohydrate ${ }^{2}$ & 135 & 84.86 & 77 & 85.37 & 0.29 & 0.0839 \\
\hline Non fibrous carbohydrates ${ }^{2}$ & 108 & 26.48 & 77 & 29.24 & 1.39 & 0.0495 \\
\hline $\mathrm{Starch}^{2}$ & 48 & 19.84 & 11 & 21.54 & 2.55 & 0.5067 \\
\hline Neutral detergent fiber ${ }^{2}$ & 427 & 54.72 & 116 & 55.14 & 0.78 & 0.5936 \\
\hline NDFap $^{2}$ & 22 & 51.91 & 24 & 52.95 & 2.49 & 0.6808 \\
\hline Acid detergent fiber ${ }^{2}$ & 337 & 29.65 & 85 & 31.04 & 0.60 & 0.0214 \\
\hline Cellulose $^{2}$ & 37 & 23.25 & 7 & 25.32 & 1.54 & 0.1877 \\
\hline Hemicellulose $^{2}$ & 329 & 26.12 & 85 & 24.01 & 0.62 & 0.0007 \\
\hline Lignin $^{2}$ & 104 & 5.55 & 51 & 5.11 & 0.36 & 0.2323 \\
\hline Crude protein ${ }^{2}$ & 438 & 7.47 & 125 & 7.21 & 0.11 & 0.0294 \\
\hline Ammoniacal nitrogen ${ }^{3}$ & 140 & 3.82 & 7 & 4.78 & 0.86 & 0.2632 \\
\hline Lactic acid ${ }^{2}$ & 40 & 2.64 & 3 & 2.99 & 1.93 & 0.8560 \\
\hline $\mathrm{pH}$ & 201 & 3.80 & 119 & 3.89 & 0.07 & 0.2370 \\
\hline Ether extract ${ }^{2}$ & 140 & 2.70 & 94 & 2.60 & 0.13 & 0.4689 \\
\hline IVDMD $^{2}$ & 99 & 65.05 & 4 & 66.01 & 4.12 & 0.8183 \\
\hline Total digestible nutrients ${ }^{2}$ & 107 & 66.79 & 25 & 64.18 & 0.94 & 0.0064 \\
\hline Net energy ${ }^{4}$ & 56 & 1.31 & 4 & 1.35 & 0.07 & 0.5461 \\
\hline Calcium $^{2}$ & 74 & 0.06 & 21 & 0.19 & 0.02 & $<0.0001$ \\
\hline Phosphorus $^{2}$ & 68 & 0.18 & 22 & 0.19 & 0.01 & 0.6497 \\
\hline
\end{tabular}

*Number of observations; SCS = Silage produced by studies about corn silage; UCS = Silage produced by studies that used corn silage in the investigation of other topics; $1=$ Percentage of natural matter; $2=$ Percentage of dry matter; $3=$ Percentage of total nitrogen; 4 = Megacalorie per kilogram of dry matter; NDFap $=$ Neutral detergent fiber content corrected for ash and protein content; IVDMD = in vitro dry matter digestibility.

Immediately after the harvest of corn plants, NFCs include sugar, pectin, and starch; however, during ensilage processing, most of the NFCs mainly content the sugars are used as substrates by bacteria during fermentation, which also generates organic acids, such as lactic and acetic acid. According to the NRC (2001), there is no pectin present in corn silage, i.e., the NFCs are basically represented by starch; therefore, the NFC content can be used as an indicator of starch quantity. There was a significant difference $(\mathrm{P}=0.0495)$ between the NFC content of the SCS (26.48) and UCS (29.24) silage. However, both values were lower than the average value (41.0\% DM) reported by the NRC (2001), which indicates either unsuitable cultivation or silage processing conditions, and there was no significant difference between the starch content of the SCS (19.84) and UCS (21.54) silage, which contradicted our conclusion based on the NFC content. This contradiction likely resulted from the different sample sizes of the two analyses (185 for NFC vs. 59 for starch), as well as the low samples size used for the analysis of starch $(\mathrm{N}=59)$. It should be noted that there would be no plausible reason to find higher levels of starch in UCS studies analyzing separately the mean values of DM obtained in SCS studies (33\%) and UCS studies (30.64\%). However, the sample sizes of the groups were also different (585 for DM vs. 59 for starch).

Together with NDF digestibility, starch content is the most desirable parameter in corn silage. The degradation of starch in the rumen contributes significantly to the production of propionate, which is the main glycemic source of ruminants and stimulates the production of milk and muscle tissue. As already mentioned, our analysis revealed that 
only a small number of studies ( $\mathrm{N}=59,20.69 \%)$ analyzed starch content (48 and 11 for SCS and UCS silage, respectively), which was negligible, when compared to the percentage of studies reporting crude protein contents. However, this may be a consequence of the complexity and difficulty of measuring starch content.

The quality of the fiber present in corn plants is another essential parameter to evaluate, since it has a direct effect on the amount of feed that animals ingest and participates in the energy value of the roughage (VAN SOEST, 1994). For example, NDF content is directly related to animal consumption, and when NDF content increases, consumption decreases, as animals that should consume silage have voluntary intake of two, three or more fold the maintenance requirement, since the production of silage for animal feed in maintenance becomes very costly when one relates the cost of silage production with animal performance, i.e., ruminant animals in maintenance preferably should acquire their diet directly from the pasture. The corn silage produced by Brazilian studies possessed high NDF contents, regardless of the purpose of the studies, and the NDF contents were not significantly different, with mean values of 54.72 and $55.14 \%$ for the SCS and UCS silage, respectively.

NDFap content, which is calculated by subtracting the ash and indigestible nitrogen in neutral detergent (i.e., protein) contents from the total NDF content, and the amplitude of the difference between the NDFap and NDF contents indicated the importance of using the corrected values (i.e., NDFap), since they provide a more accurate estimation of silage quality. Our analysis revealed that the NDFap contents of the SCS and UCS silage were 2.81 and $2.19 \%$ less than their respective total NDF contents, and since an overestimation of NDF content by two percentage points can impair the ruminal metabolism of lactating cows by favoring metabolic disorders, such as clinical and subclinical acidosis, we concluded that the total NDF content should be corrected for ash and protein contents.
In this context, from the various variables that contribute to silage quality, correctly identifying the maturity stage at harvest $(30-35 \% \mathrm{DM})$ is an important factor in determining the final NDF and starch contents, both of which directly influence the efficiency and cost of production. Therefore, breeding programs for producing corn hybrids to be used in silage for feeding dairy cows should focus on increasing the starch content and digestibility of the NDF fraction (FERRARETTO et al., 2015). However, Brazilian papers published in the past two decades have not focused on these aspects.

The acid detergent fiber content is an important indicator of digestibility, with lower acid detergent fiber contents related to higher digestibility. We found that UCS silage had higher acid detergent fiber contents $(31.04 \%$ the DM), which indicated lower digestibility than the SCS silage. This was also corroborated by the lower mean total digestible nutrient content $(64.18 \% \mathrm{DM})$ of the UCS silage. These results are not surprising, since the same care is not usually taken when using standard silage production methods, compared to that taken when producing SCS silage, which had a mean acid detergent fiber content of $29.65 \%$ and a total digestible nutrient content of $66.79 \%$. In contrast, there were no significant differences between the in vitro dry matter digestibility $(\mathrm{P}=0.8183)$ or net energy content $(\mathrm{P}=0.5461)$ of the two groups; however, it should be emphasized that the lack of statistical difference is not uncommon when comparing in vitro dry matter digestibility, owing to the incubation times used. For this reason, Velho et al. (2014) recommended that comparing the in vitro digestibility of corn silages be done using a 24-h incubation, since longer incubation periods indicate indigestibility and generally mask any differences that might be present.

To determine the digestibility of both DM and cell wall material, it is crucial to know the composition and structure of corn stalks used for silage production, since the proportion of tissues and components that make up the stalks are decisive factors for 
determining digestibility. Among the components of the cell wall, lignin causes a more negative effect on digestibility, often by its distribution in comparison to other components of the cell wall (FERREIRA et al., 2007). Low levels of lignin $(<5 \%$ DM) are necessary, since a small amount is necessary to sustain the standing plant. However, as corn plants develop, their lignin content increases, incrusted in cellulose and hemicelluloses, mainly when reaching physiological maturity, becoming indigestible and reducing the nutritive value of the forage by decreasing the ruminal degradation (MASSÉ et al., 2016). Thus, it is important to process ensilage at the appropriate time, so as not to deteriorate the quality of the plant. In the present study, we observed that the SCS and UCS silage contained lignin levels of 5.55 and $5.11 \%$ DM, respectively.

Although cellulose is the main fibrous carbohydrate in corn silage, it was rarely reported ( $\mathrm{N}=37$ for SCS silage and $\mathrm{N}=7$ for UCS silage), and no significant difference was observed between the groups $(\mathrm{P}=0.1877)$. Probably since hemicelluloses have varied constitution and make up the portion of the NDF that can be fully used by ruminants, we found that more studies estimated hemicellulose contents ( $\mathrm{N}=329$ for SCS silage and $\mathrm{N}=85$ for UCS silage) and that the hemicellulose contents were significantly greater in the SCS silage (26.12\% DM) than in the UCS silage (24.01\% DM; $\mathrm{P}=0.0007)$.

As plants develop, their lignin content increases, incrusted in cellulose and hemicelluloses, mainly when reaching physiological maturity, becoming indigestible and reducing the nutritive value of the forage by decreasing the ruminal degradation (MASSÉ et al., 2016). Thus, it is important to process ensilage at the appropriate time, so as not to deteriorate the quality of the plant. Low levels of lignin $(<5 \% \mathrm{DM})$ are necessary because a small amount is necessary to sustain the standing plant. In the present study, we observed that the SCS and UCS silage contained lignin levels of 5.55 and $5.11 \%$ DM, respectively.
There was moreover, a significant difference was observed $(\mathrm{P}=0.0294)$ in the crude protein content of the SCS (7.47\% DM) and UCS (7.21\% DM) silage, which can likely be attributed to the amount of data obtained and the magnitude of the standard error, since significant differences typically result when the standard deviation and coefficient of variation are reduced in relation to the mean. The use of corn silage with higher crude protein contents can allow producers to decrease the amount of protein included in feeding concentrates, which subsequently reduces feed cost and provides a greater stimulus for the production of microbial protein and, therefore, metabolizable protein.

The effectiveness of the fermentation process in silage production can be evaluated through the analysis of several variables, including $\mathrm{pH}$ and contents of organic acid content and ammoniacal nitrogen $\left(\mathrm{N}-\mathrm{NH}_{3}\right)$, and corn silage that has undergone adequate fermentation possesses a $\mathrm{pH}$ of 3.8-4.2, lactic acid content of 6.0-8.0\% DM, and $\mathrm{N}-\mathrm{NH}_{3}$ content of less than $10 \%$ of the total nitrogen content (FERREIRA, 2001). Since the $\mathrm{pH}$ of silage is derived from the quantity of organic acids, mainly lactic acid, and is, therefore, a good indicator of the conservation process, $100 \%$ of the UCS studies evaluated $\mathrm{pH}$, whereas only $43.13 \%$ of the SCS group evaluated $\mathrm{pH}$. The $\mathrm{pH}$ values reported by the SCS and UCS studies indicated that the fermentation process was adequate; however, this was difficult to verify, owing to the small number of studies that reported the concentrations of lactic acid and other organic acids, and it was impossible to include the occurrence of organic acids in our meta-analysis because none of the papers included in the present study reported it. Thus, only the lactic acid contents of the SCS (2.64\% DM) and UCS $(2.9 \% \mathrm{DM})$ silage were inadequate. $\mathrm{N}-\mathrm{NH}_{3}$ content $(\%$ total $\mathrm{N})$ indicates the amount of protein that has degraded during the fermentation phase, as well as the occurrence of excessive heating of the silo. The SCS studies showed a greater interest $(\mathrm{N}=140)$ in monitoring $\mathrm{N}-\mathrm{NH}_{3}$ content than the UCS studies $(\mathrm{N}$ 
$=7$ ), which typically failed to report the amount of crude protein that was degraded and transformed into ammonia.

Since the $\mathrm{pH}$ of silage is derived from the quantity of organic acids, mainly lactic acid, and is, therefore, a good indicator of the conservation process, $100 \%$ of the UCS studies evaluated $\mathrm{pH}$, whereas only $43.13 \%$ of the SCS group evaluated $\mathrm{pH}$. The $\mathrm{pH}$ values reported by the SCS and UCS studies indicated that the fermentation process was adequate; however, this is difficult to verify, owing to the small number of studies that reported the concentrations of lactic acid and other organic, and it was impossible to include the occurrence of organic acids in our meta-analysis because none of the papers included in the present study reported it.

Although the content of the ether extract varied widely $(0.43-6.65 \%$, mean $=2.65 \% ; \mathrm{N}=234)$, there was no significant difference between the ether extract levels of the SCS and UCS silage. The wide variation may be attributed to the quantities of grains present in the silage.

Calcium and phosphorus are important in the nutrition of lactating cows; however, the two macrominerals can usually only be supplemented via mineral salts. Despite this, the contents of both minerals were reported more than starch content, and our analysis indicated that calcium content was higher in UCS silage than in SCS silage, whereas the phosphorous content of the two groups was similar.

The partial mean results between 2009 and 2015 of the Corn Silage Competition of the ABC Foundation (FUNDAÇÃO ABC, 2015) (DM = $31.7 \% ; \mathrm{pH}=3.8 ; \mathrm{NDF}=45.1 \% \mathrm{DM}$; starch content $=33.0 \% \mathrm{DM}$; and $\mathrm{TDN}=70.7 \% \mathrm{DM}$ ), with samples taken from trench or surface silos, demonstrated that Brazil has the capacity to produce corn silage with a quality that is similar to that of silage produced in the United States of America. Therefore, it is essential to achieve this quality in a larger number of rural businesses in Brazil, in order to increase animal production and, consequently, the generation of foreign exchange.

\section{Conclusions}

As the main conclusion of our meta-analysis, we found that the corn silage produced by studies about corn silage (SCS) had a greater nutritional value than corn silage produced by studies that used corn silage (UCS) in investigations of other topics. In addition, we also found that there was a paucity of information regarding organic acid content, since most scientific studies that produce corn silage in Brazil do not report complete chemical composition.

\section{Acknowledgements}

We thank the Financiadora de Estudos e Projetos (FINEP) of the Ministry of Science and Technology (MCT), through the financial resources available in the Public Call MCT/FINEP/CT-INFRA - CAMPI REGIONAIS - 01/2010, which allowed the Federal University of Santa Maria - Palmeira das Missões Campus to establish the Plant-Animal Interface Research Laboratory, containing the Meta-analysis Studies Laboratory, under the coordination of Prof. João Pedro Velho.

\section{References}

FERRARETTO, L. F.; FONSECA, A. C.; SNIFFEN, C. J.; FORMIGONI, A.; SHAVER, R. D. Effect of corn silage hybrids differing in starch and neutral detergent fiber digestibility on lactation performance and total-tract nutrient digestibility by dairy cows. Journal of Dairy Science, Madison, v. 98, n. 1, p. 395-405, 2015.

FERREIRA, G. D. G.; EMILE, J. C.; BARRIÈRE, Y; JOBIM, C. C. Caracterização morfoanatômica do colmo de híbridos de milho para avaliar a qualidade de silagem. Acta Scientiarum. Animal Sciences, Maringá, v. 29, n. 3, p. 249-254, 2007.

FERREIRA, J. J. Estágio de maturação ideal para ensilagem do milho e do sorgo. In: CRUZ, J. C.; PEREIRA FILHO, I. A.; RODRIGUES, J. A. S.; FERREIRA, J. J. (Ed.). Produção e utilização de silagem de milho e sorgo. Sete Lagoas: Embrapa Milho e Sorgo, 2001. p. 405-428. 
FUNDAÇÃO ABC. Concurso de silagem. Castro: Fundação ABC, 2015. Disponível em: <http://www. fundacaoabc.org.br/>. Acesso em: 10 nov. 2015.

HENDERSON, C. H. Best linear estimation and prediction under a selection model. Biometrics, Washington D.C., v. 31, n. 2, p. 423-447, 1975.

JOBIM, C. C.; NUSSIO, L. G.; REIS, R. A.; SCHMIDT, P. Avanços metodológicos na avaliação da qualidade da forragem conservada. Revista Brasileira de Zootecnia, Viçosa, MG, v. 36, p. 101-119, 2007. Suplemento especial.

LOVATTO, P. A.; LEHNEN, C. R.; ANDRETTA, I.; CARVALHO, A. D.; HAUSCHILD, L. Meta-análise em pesquisas científicas - enfoque em metodologias. Revista Brasileira de Zootecnia, Viçosa, MG, v. 36, p. 285-294, 2007. Suplemento Especial.

LUIZ, A. J. B. Meta-análise: definição, aplicações e sinergia com dados espaciais. Cadernos de Ciência \& Tecnologia, Brasília, v. 19, n. 3, p. 407-428, 2002.

MARÍN, A. L. M.; SÁNCHEZ, N. N.; SIGLER, A. I. G.; BLANCO, F. P.; GARCÍA, V. D.; RUIPÉREZ, F. H. Metaanálisis del uso de semillas y aceites en la dieta de ovejas y cabras. Pesquisa Agropecuária Brasileira, Brasília, v. 50, n. 9, p. 821-828, 2015.

MASSÉ, D. I.; JARRET, G.; HASSANAT, F.; BENCHAAR, C.; SAADY, N. M. C. Effect of increasing levels of corn silage in an alfalfa-based dairy cow diet and of manure management practices on manure fugitive methane emissions. Agriculture, Ecosystems and Environment, Amsterdam, v. 221, p. 109-114, 2016.

NATIONAL RESEARCH COUNCIL - NRC. Nutrient of requirements of dairy cattle. $7^{\text {th }}$ ed. Washington: National Academic Press, 2001. 381 p.

NUSSIO, L. G.; CAMPOS, F. P. de; DIAS, F. N. Importância da qualidade da porção vegetativa no valor alimentício da silagem de milho. In: SIMPÓSIO SOBRE PRODUÇÃO E UTILIZAÇÃO DE FORRAGENS CONSERVADAS, 2001, Maringá. Anais... Maringá: UEM/CCA/DZO, 2001. p. 127-145.
RABIEE, A. R.; BREINHILD, K.; SCOTT, W.; GOLDER, H. M.; BLOCK, E.; LEAN, I. J. Effect of fat additions to diets of dairy cattle on milk production and components: a meta-analysis and meta-regression. Journal of Dairy Science, Madison, v. 95, n. 6, p. 32253247, 2012.

RESENDE, F. D. de; SIGNORETTI, R. D.; COAN, R. M.; SIQUEIRA, G. R. Terminação de bovinos de corte com ênfase na utilização de volumosos conservados. In: REIS, R. A.; SIQUEIRA, G. R.; BERTIPAGLIA, L. M. A.; OLIVEIRA, A. P.; MELO, G. M. P.; BERNARDES, T. F. (Ed.). Volumosos na produção de ruminantes. Jaboticabal: Fundação de Apoio à Pesquisa, Ensino e Extensão, FUNEP, 2005. v. 1, p. 83-106.

SAUVANT, D.; SCHMIDELY, P.; DAUDIN, J. J.; STPIERRE, N. R. Meta-analyses of experimental data in animal nutrition. Animal, Cambridge, v. 2, n. 8, p. 12031214, 2008.

SILVA, M. S. J. da; JOBIM, C. C.; POPPI, E. C.; TRES, T.; OSMARI, M. P. Production technology and quality of corn silage for feeding dairy cattle in Southern Brazil. Revista Brasileira de Zootecnia, Viçosa, MG, v. 44, n. 9, p. 303-313, 2015.

STATISTICAL ANALYSIS SYSTEM INSTITUTE SAS Institute. Release 8.02.2000. Cary: SAS Institute, Inc., 2002.

VAN SOEST, P. J. Nutritional ecology of the ruminant. Ithaca: Cornell University, 1994. 476 p.

VELHO, J. P.; MÜHLBACH, P. R. F.; GENRO, T. C. M.; BARCELLOS, J. O. J.; BRACCINI NETO, J.; SILVA, R. S. M. Modelos matemáticos para ajuste da produção de gases in vitro em diferentes tempos de incubação e cinética ruminal de silagens de milho. Semina: Ciências Agrárias, Londrina, v. 35, n. 4, p. 2531-2540, 2014. Suplemento. 
